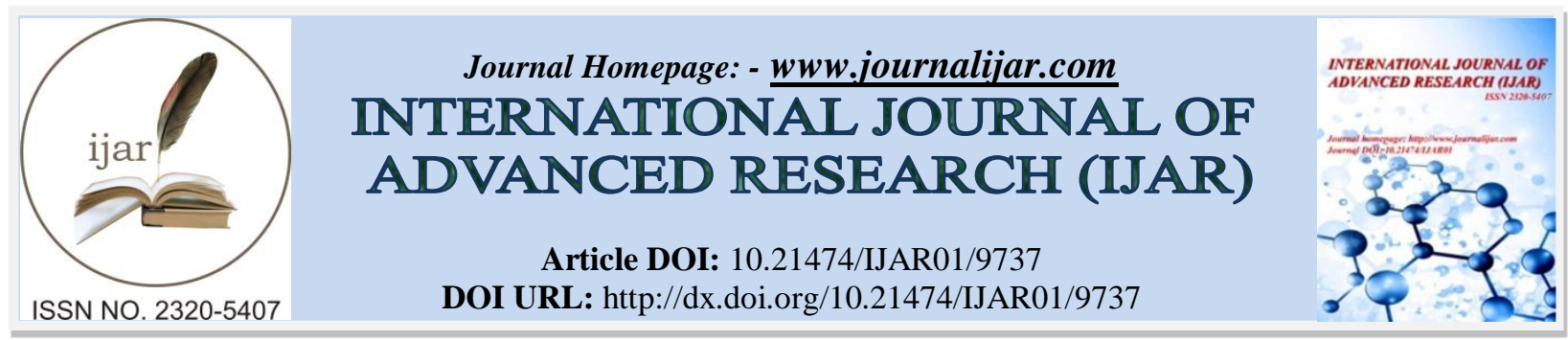

RESEARCH ARTICLE

\title{
LEAN MANUFACTURING SYSTEM ADOPTION AND PROFITABILITY: NIGERIAN FOOD AND BEVERAGES FIRMS' POSITION.
}

\author{
Ariguzo V. A., Amos N. B., Egwakhe A. J. and Adefulu A. D. \\ Department of Business Administration \& Marketing, Babcock University, Ilishan-Remo, Ogun State, Nigeria.
}

\section{Manuscript Info}

Manuscript History

Received: 12 July 2019

Final Accepted: 14 August 2019

Published: September 2019

Key words:-

Lean Manufacturing, Blue Ocean Strategy, Profitability.

\begin{abstract}
The stiff global competition has forced some firms to re-strategize and adopt fitness properties to induce incremental changes as profitability becomes a paramount focus. The study assessed lean manufacturing system adoption ability to stimulate profitability, within Nigerian food and beverage sub-sector. Emphasis was placed on waste reduction, labour optimization and inventory control to firms' profit before tax. The comparative approach emerged from ex-post-facto design pillared on quantitative data from three top players in Nigeria, pre and postimplementation of the lean process. The study found lean manufacturing to have significantly affected the profitability in Nestle and Cadbury Plc, but observed no changes in Unilever. The study recommends that lean manufacturing system be adopted after the required internal re-engineering and sensitization have been carried out in the firms to forestall resistance and embracing of the benefits accruable from its adoption.
\end{abstract}

Copy Right, IJAR, 2019. All rights reserved.

\section{Introduction:-}

Achieving profitability remains paramount for the survival and continuous existence of every firm, as well as a deserving reward to the providers of capital. However, the modalities employed and the aftermaths are never the same across firms operating within the same economy. This is conventionally attributed to increasing competitive landscape where "customers remain king" and a burning desire to meet up with changing demands and preferences, despite maintaining high quality standards and pocket friendly prices. Hence, managers are continuously saddled with the responsibility of achieving this goal, yet challenges within the manufacturing floor are often along the supply value chain. The challenges along the strategic inputs affect the efficient running of the manufacturing process. This phenomenon bring about a continuous thinning out of profitability lines, despite growing competition and increasing demand, keeping firms battling for survival in a red ocean environment (Lainos, 2011).

In Nigeria, the declining profitability within the manufacturing sector even seems to be worsening, despite the positive growth in the economy since the nation exited recession in 2018 (Onuba, 2018). Out of the thirteen subsectors within the manufacturing industry, only five recorded marginal increases between the last quarter in 2017 and first quarter in March 2018. However, the remaining eight sub-sectors including the food and beverage sector recorded a decline in productivity and contribution to the country's Gross Domestic Product (GDP) (Onuoha, 2018; Ududechinyere, Eze, \& Nweke, 2018). Figures as revealed by National Bureau of Statistics (NBS) in 2018 revealed that a decline was in productivity in oil refining, from $\$ 42.69 \mathrm{bn}$ to $\$ 41.55 \mathrm{bn}$; food, beverage and tobacco, from

Corresponding Author:-Ariguzo V. A.

Address:-Department of Business Administration \& Marketing, Babcock University, Ilishan-Remo, Ogun State, Nigeria. 
$\$ 1.21 \mathrm{tn}$ to $\$ 1.19 \mathrm{tn}$; textile, apparel and footwear, from $\$ 642.55 \mathrm{bn}$ to $\$ 610.64 \mathrm{bn}$; and chemical and pharmaceutical products, from $\$ 58.91 \mathrm{bn}$ to $\$ 55.23 \mathrm{bn}$ (Onuoha, 2018).

A similar trend was observed in data provided by NBS (2019) where the whole manufacturing sector suffered a setback of N78bn, when the figures between the last quarter of 2018 and first quarter in 2019 were compared (Onuoha, 2019). Although four sub-sectors recorded marginal improvement in productivity, the remaining nine subsectors declined, with oil refining dropping from $\$ 40.03 \mathrm{bn}$ to $\$ 14.67 \mathrm{bn}$; food, beverage and tobacco from $\$ 387.98 \mathrm{bn}$ to $\$ 359.51 \mathrm{bn}$; paper products from $\$ 14.13 \mathrm{bn}$ to $\$ 13.35 \mathrm{bn}$; chemical and pharmaceutical products from $\$ 40.34$ bn to $\$ 37.07$ bn (Okon, 2019; Onuoha, 2019).

Furthermore, the aggregate Manufacturers CEO's Confidence Index report (2019) for the second quarter of 2019 revealed an index of 50.9, as against 51.3points recorded in the first quarter of 2019 (Nkeiru, 2019). This declining index of 50.9 revealed a drop in confidence level and shrinking of a sector expected to jumpstart the country's economy. The weak performance and decline in confidence index is attributable to the persistence of many operating challenges limiting manufacturing activities both externally and internally, other challenges hindering production efficiency in the sector (Okon, 2019; Ududechinyere, Eze, \& Nweke, 2018). Hence, firms are tending towards reducing internal cost elements through waste elimination to improve efficiency, productivity and profitability of their organizations.

The elimination of waste in all its forms is targeted at creating a "blue ocean" environment capable of reducing firm rivalry through innovative strategies which are imperative (Akinwale, Dada, Oluwadare, Jesuleye, \& Siyanbola, 2012). Hence, the suggestion that the lean manufacturing process could provide some level of efficiency capable of reducing costs and improving profitability of the firms (Onwughalu, Okeke, \& Henry-Chibor, 2017). This is because lean manufacturing has been known to reduce waste along the lines of labour, material and money (Almusawi, Almagtome, Shaker, 2019). It based on this premise that this study argued that lean manufacturing system adopt affect profitability of selected firms in the Nigerian food and beverage sub-sector. The paper is structured as such; introduction, literature review, methodology, presentation of results and discussion of findings, conclusions and recommendations.

\section{Literature Review}

Adoption of the lean manufacturing systems enable firms increase their manufacturing strength, and efficiency, through various cost reduction mechanisms targeted at elimination of waste. According to Alhuraish, Robledo, and Kobi (2016), lean manufacturing refers to the method adopted to reduce production cost with minimal waste. It could also be viewed as a business strategy that enhances customer satisfaction through increased process improvements and improved bottom line results (Snee, 2010). Lean is beneficial for not just its improvement in procedure, reduction in inventory and enhanced ergonomics, but also allows the company to fine-tune its understanding of customers' changing dynamics in terms of demand and quality (Keitany \& Riwo-Abudho, 2014). The ideology of process improvement involves major input factors such as inventory, labour, machine hours and finance, and elimination waste completely from the process. Waste has classified by Lareau (2003) involves people (human elements in a strategic drift from the firms' goals); information (lack of controlling in variability, standardization and errors, but high level monitoring only); waiting and motion process (missing irrelevant and inaccurate information) and asset waste (idle machinery, office building or assets).

Various authors (Braiden \& Morrison, 1996; Modi \& Thakkar, 2014; Wafa, Yasin, \& Swinehart, 1996) have suggested numerous techniques utilized in the lean system to eliminate waste, reduce lead time and increase profitability. Some of these include the $5 \mathrm{~s}$ (sort, straighten, shine, standardize and sustain) which reduces hidden waste in the plant, improves quality and safety and increases profit (Modi \& Thakkar, 2014). Another is the Just-inTime (JIT) methods targeted at reducing holding cost of inventory, and improving cost of sales (Wafa, Yasin, \& Swinehart, 1996), while the Kaizen philosophy which is a continuous improvement tool (Braiden \& Morrison, 1996) is targeted at the whole processing of helping to make things better with the production process. Single Minute Exchange of Die (SMED) concept target at minimizing time wastage by ensuring rapid and efficient conversion process from one product to another, lowers cost, greater flexibility and higher thought out (Smeds, 1994) and Total Productive Maintenance (TPM) a system of using machines, processes, people and equipment to maintain and improve the integrity of quality systems and production (Onwughalu, Okeke, \& Henry-Chibor, 2017), are other lean tools. 


\section{Profitability}

Profitability is a relative measure of capacity to earn returns on some investment over a period of time (Egwakhe, Adefulu, \& Ariguzo, 2019). Earlier scholars (Owolabi and Obida, 2012; Sivathaasan, Tharanika, Sinthuja, \& Hanitha, 2013) describe profitability as the capacity to make profit from all the activities of a business, and the assessment of efficient use of firms resources in value-addition to the entire organization. Ideally, firms are profitable when they earn profits from survival strategies, growths and expansions attained over time (Amos, 2017). To access the profitability of any firm, it could be viewed subjectively (perceptions of individuals based on cost reduction strategies or year-on-year growth relative to industry where the firm plays) as posited by (Mwelu, Rulangaranga, Watundu, \& Tindiwensi, 2014; Hoang, 2015) or objectively (measured with financial ratios and result such as profit after tax (PAT), return on assets (ROA), gross profit ratios (GPR), return on capital employed (ROCE) and other measures which demonstrate a firm's operational efficiency as suggested by Nishanthini and Nimalathasan, (2013) and Sivathaasan et al (2013).

\section{Lean manufacturing and Profitability}

Scholarly insight into manufacturing firms in Uganda by Mwelu, Rulangaranga, Watundu, and Tindiwensi (2014), indicated that lean manufacturing (labour productivity, time efficiency, and quality output) has a strong influence on profitability. The study revealed that a $41.4 \%$ positive change occurred in the profitability of the firms in Uganda after adopting tools such as six sigma, kaizen and total quality management tools. Similar positive results were observed in empirical studies that investigated the effect of lean manufacturing strategy and profitability, carried out by Chamazkoti, Namadchian and Davoudi (2012) on manufacturing firms in Tehran, and Kumar, Dhermendra and Naveen (2012) on firms in the automobile manufacturing sub-sector. A divergence was observed from the studies of Okpala (2013) and Panizzolo, Garengo, Sharma, and Gore (2012).

Okpala (2013) observed lean manufacturing from the six sigma methodologies against profitability from manufacturing small and medium enterprises in Nigeria, and found that it had no influence on profit levels. This observation was attributed to unwilling leadership support, followers' buy-in, and poor documentation of the lean success evidences. The divergence observed from Okpala's study (2013) was previously established by Panizzolo et al (2012) with evidence from Indian SMEs which discovered that LMS did not affect profitability due to restrictions that dwelt on culture, skills and knowledge gaps, and top management commitment. Another perspective was observed from the study of Khlat, Harb, and Kassem (2014) carried out on Lebanese Pharmaceutical firms, which discovered that lean system could be time consuming than time saving due to the constant recording of effect, as such impacting on time schedules slated from actual works hours and negatively affecting profitability. Camuffo and Volpato (1995) also discovered that Lean manufacturing implementation brought about negative effect on employees' productivity due to the lack of involvement of the employees expected to undertake the change process, leading to major downturns in productivity and invariably huge financial loss. Scholars differ in results and their findings, despite the similar application in varying manufacturing sub-sectors, and this could be attributed to the differences observed in the lean tools applied by the firms, cultural disposition of the implementers, the geographical locations or even the analytical tools adopted.

\section{Methodology:-}

This study employed the usage of an ex-post-facto research design which was deemed appropriate because it entails the collection of data from secondary sources over a period of time, in order to establish the relationship and effect existing among the variables of interest. The study carried out a post-effect review of three determining factors of LMS (Material Leanness, Employees Leanness, and Money Leanness) on the Profit (PAT) of multinational Food and beverages firms in Nigeria. A comparison was done amongst the three multinational firms sampled along preand-post adoption performance. Time series data was collected for a period of 25years (1994-2018) which makes up the total number observations. The reliability of the data was anchored on the legal provision regulating the financial report of these firms to the Nigeria Stock Exchange Commission and the integrity of the Audit Firms that certified the financial reports before public disclosure.

\section{Model Construction}

The hypothesis for the study was tested using the regression tool, derived from the econometric equation developed along the proposition. The individual influence of these lean manufacturing dimensions was sought followed by a comparative examination of the overall effect of lean manufacturing on the profit after tax of the sampled firms. The predicted model relating inventory, number of employees, and cost of sales to profit is presented using the linear regression model as: 


$$
\mathrm{PAT}=\alpha_{0}+\beta_{1} C O S A+\beta_{2} \text { TOTINV }+\beta_{3} N O E+1 t
$$

Where:

$$
\begin{aligned}
& \text { PAT }=\text { Profit after Tax } \\
& \text { COSA }=\text { Cost of Sales } \\
& \text { TOTINV = Total Inventory } \\
& \text { NOE }=\text { Number of Employees } \\
& \beta_{0}=\text { Constant term associated with the regression model } \\
& \beta_{1}=\text { coefficient of cost of sales } \\
& \beta_{2}=\text { coefficient of total inventory } \\
& \beta_{3}=\text { coefficient of number of employees }
\end{aligned}
$$

The hypothesis was tested using OLS method of estimation within the multiple regression analysis.

\section{Result Findings and Discussions:-}

The results of the regression analysis carried out on the data are as presented with pre and post LMS adoption comparatively investigated. The coefficient, t-stat and probability formed the background upon which the results were compared. Table 1 shows the multiple regression result of the effect of lean implementation measured by cost

\begin{tabular}{|c|c|c|c|c|c|c|c|c|}
\hline \multirow[t]{2}{*}{ Variables } & \multicolumn{4}{|l|}{ Before } & \multicolumn{4}{|l|}{ After } \\
\hline & Coeff & Std Error & T-Stat & Prob & Coeff & Std Error & T-Stat & Prob \\
\hline C & 88231.24 & 2170204. & 0.041 & 0.9701 & -9544060 & 11581904 & -0.824 & 0.4703 \\
\hline COSA & 0.258423 & 0.128751 & 2.007 & 0.1384 & 0.284443 & 0.058838 & 4.834 & 0.0169 \\
\hline TOTINV & 0.067377 & 0.474313 & 0.142 & 0.8960 & -0.813275 & 0.481998 & -1.687 & 0.1901 \\
\hline NOE & -197.2215 & 1626.031 & -0.121 & 0.9111 & 8047.554 & 7807.121 & 1.031 & 0.3785 \\
\hline $\mathbf{R}^{2}$ & \multicolumn{4}{|l|}{$\mathbf{0 . 8 3 1 7 2 7}$} & \multicolumn{4}{|c|}{0.979277} \\
\hline Adjusted $\mathbf{R}^{2}$ & \multicolumn{4}{|l|}{0.663453} & \multicolumn{4}{|l|}{0.958555} \\
\hline F-Statistic & \multicolumn{4}{|l|}{4.942710} & \multicolumn{4}{|l|}{47.25633} \\
\hline $\begin{array}{l}\text { Prob (F- } \\
\text { Statistic) }\end{array}$ & \multicolumn{4}{|l|}{0.111079} & \multicolumn{4}{|l|}{ 0.005033* } \\
\hline
\end{tabular}
of sale (COSA), total inventory (TOTINV) and number of employees (NOE) on profit after tax (PAT) of Nestle Nigeria Plc. before and after the implementation of the lean system. The result shows that for the period before lean, both COSA and TOTINV have positive effect on PAT, while NOE has a negative effect on PAT. The period after the implementation of lean shows that COSA and NOE both have positive effect on PAT, while TOTINV has a negative effect on PAT as revealed by the signs of the coefficients. The total inventory coefficient became negative after the implementation of the lean system which implies that Nestle Nigeria Plc has not scaled down the volume of inventory held to an optimum point.

Table 1:-Regression estimate of Nestle Nigeria Plc. - Before and After Lean Manufacturing Implementation

Source: Researcher's study, 2019

$\mathrm{PAT}=\alpha_{0}+\beta_{1} C O S A+\beta_{2 T O T I N V}+\beta_{3 N O E+} 1 t$

$\mathrm{PAT}=88231.24+0.258423 \mathrm{COSA}+0.067377 \mathrm{TOTINV}-197.2215 \mathrm{NOE} \quad$ Before

PAT $=-9544060+0.284443 \mathrm{COSA}-0.813275 \mathrm{TOTINV}+8047.554 \mathrm{NOE} \quad$ After

Also, the size of the coefficients reveals that before the implementation of lean, 1 change in COSA and TOTINV caused a $\$ 0.258$ increase (in Thousand) and $\$ 0.0673$ increase (in Thousand) in PAT respectively, while one employee added to the workforce of Nestle also resulted in 194.22 decrease (in Thousand) in PAT. However, the size of the coefficients after the implementation of the lean system shows that a change in COSA and TOTINV brought about $¥ 0.284$ increase (in Thousand) and $¥ 0.813$ decrease (in Thousand) in PAT respectively, while one employee added to the workforce of Nestle increased the PAT by 8047 increase (in Thousand). 
Furthermore, the Adjusted R-squared shows that about $66 \%$ variations in PAT before the implementation of lean can be attributed to the influence of the explanatory variables employed in the study while the remaining $34 \%$ variations in the PAT were caused by other factors not included in this model. Also, the adjusted R-squared for the period after the implementation of the lean system shows that about $96 \%$ variations in PAT can be attributed to the influence of all our explanatory variables while the remaining 4\% variations in the PAT are caused by other factors not captured in this model. This implies that the lean implementation variables are more effective on the Profit after tax of Nestle Nigeria Plc.

The probability of the F-statistic of the models stood at $11 \%$ and $1 \%$ for the period before and after the implementation of the lean system respectively. Implying that Cost of sales, total Inventory and Number of employees have an insignificant effect on Profit after Tax of Nestle Nig. Plc before the implementation of lean while after the implementation of lean, COSA, TOTINV, and NOE have a significant effect on PAT. Therefore, it can be concluded that lean manufacturing implementation has a significant effect on the profit after tax of Nestle Nigeria Plc.

Table 2:-Regression Estimate of Unilever Nigeria Plc. - Before and After Lean Manufacturing Implementation

\begin{tabular}{|c|c|c|c|c|c|c|c|c|}
\hline \multirow[t]{2}{*}{ Variables } & \multicolumn{4}{|l|}{ Before } & \multicolumn{4}{|l|}{ After } \\
\hline & Coeff & Std Error & T-Stat & Prob & Coeff & Std Error & T-Stat & Prob \\
\hline $\mathbf{C}$ & -14608266 & 3197894 & -4.568 & 0.0187 & 5064405 & 6160759. & 0.822 & 0.4713 \\
\hline COSA & 0.518148 & 0.144505 & 3.585 & 0.0371 & 0.298569 & 0.225316 & 1.325 & 0.2770 \\
\hline TOTINV & -0.967152 & 0.331315 & -2.919 & 0.0615 & -0.701359 & 0.761273 & -0.921 & 0.4248 \\
\hline NOE & 7567.403 & 1623.104 & 4.662 & 0.0186 & -4918.470 & 4392.701 & -1.119 & 0.3444 \\
\hline $\mathbf{R}^{2}$ & \multicolumn{4}{|l|}{0.934295} & \multicolumn{4}{|c|}{0.516247} \\
\hline $\begin{array}{l}\text { Adjusted } \\
\mathbf{R}^{2}\end{array}$ & \multicolumn{4}{|l|}{0.868590} & \multicolumn{4}{|c|}{0.032494} \\
\hline F-Statistic & \multicolumn{4}{|l|}{14.21949} & \multicolumn{4}{|l|}{1.067171} \\
\hline $\begin{array}{l}\text { Prob (F- } \\
\text { Statistic) }\end{array}$ & \multicolumn{4}{|l|}{$0.028022 *$} & \multicolumn{4}{|l|}{0.479317} \\
\hline
\end{tabular}

Dependent Variable: Pat

*Significance level 0.05

Source: Researcher's study, 2019

$\mathrm{PAT}=\alpha_{1}+\beta_{1} C O S A+\beta_{2}$ TOTINV $+\beta_{3 N O E+1} t$

PAT $=-14608266+0.518418 \mathrm{COSA}-0.967152 \mathrm{TOTINV}+7567.403 \mathrm{NOE}$

$\mathrm{PAT}=5064405+0.298569 \mathrm{COSA}-0.701359 \mathrm{TOTINV}-4918.470 \mathrm{NOE}$

Before

\section{Interpretation of Result}

The Table 2 shows the multiple regression result of the effect of lean implementation measured by cost of sales (COSA), total inventory (TOTINV) and number of employees (NOE) on profit after tax (PAT) of Unilever Nigeria Plc before and after the implementation of the lean system. The result reveals that for the period before the adoption of the lean system, both COSA and NOE have positive effect on PAT, while TOTINV has a negative effect on PAT. The period after the implementation of the lean system shows that COSA has a positive effect on PAT, while both TOTINV and NOE have negative effect on PAT as shown by the signs of the coefficients, which is not in accordance with the a-priori expectation because total inventory and number of employees was expected to have a positive coefficient after the implementation of the lean system but it still showed a negative coefficient which could be as a result of the emotional attachment to employees which prevented the company from scaling down the number of employees to an optimum size. In the same vein, too much stock was held in inventory as revealed by the slack in the system which could also be a cause of the negative coefficient.

Also, the size of the coefficients shows that before the implementation of the lean system, 1 change in COSA and TOTINV brought about 0.518 increase (in Thousand) and $\$ 0.96715$ decrease (in Thousand) in PAT respectively, while one employee added to the workforce of Unilever also caused a $\$ 7567$ increase (in Thousand) in PAT. However, the size of the coefficients after the implementation of lean showed that a 1 change in COSA and TOTINV caused a $¥ 0.299$ increase (in Thousand) and $\$ 0.7013$ decrease (in Thousand) in PAT respectively, while one employee added to the workforce of Unilever resulted in 4918 decrease (in Thousand) in PAT. Furthermore, the Adjusted R-squared showed that about $87 \%$ variations in PAT before the implementation of lean can be 
attributed to the influence of all our explanatory variables while the remaining $13 \%$ variations in the respective dependent variable were caused by other factors not included in this model. Also, the adjusted R-squared for the period after the implementation of the lean system shows that only about 3\% variations in PAT can be attributed to the influence of all our explanatory variables while the remaining $97 \%$ variations in the PAT are caused by other factors not captured in the model. This implies that the lean implementation variables are more effective on the Profit after tax of Unilever Nigeria Plc before its official implementation.

The probability of the F-statistic of the models stood at 3\% and $49 \%$ for the period before and after the implementation of lean respectively. Implying that Cost of sales, total Inventory and Number of employees have a significant effect on Profit after Tax of Unilever Nig. Plc before the implementation of lean while after the implementation of lean, COSA, TOTINV, and NOE have an insignificant effect on PAT. Therefore, it can be concluded that the implementation of the Lean system for Unilever Nigeria Plc has no significant effect in the Profit after tax of the company.

Table 3:-Regression Estimate of Cadbury Nigeria Plc before and After Lean Manufacturing Implementation

\begin{tabular}{|c|c|c|c|c|c|c|c|c|}
\hline \multirow[t]{2}{*}{ Variables } & \multicolumn{4}{|l|}{ Before } & \multicolumn{4}{|l|}{ After } \\
\hline & Coeff & Std Error & T-Stat & Prob & Coeff & Std Error & T-Stat & Prob \\
\hline $\bar{C}$ & 380264.3 & 339189.1 & 1.121 & 0.3788 & 18176132 & 16417419 & 1.107 & 0.3490 \\
\hline COSA & 0.119292 & 0.057798 & 2.063 & 0.1751 & -0.260971 & 0.520870 & -0.501 & 0.6508 \\
\hline TOTINV & -0.049096 & 0.168802 & -0.290 & 0.7986 & 0.626734 & 1.258330 & 0.498 & 0.6527 \\
\hline NOE & -77.61601 & 99.53946 & -0.779 & 0.5172 & -9977.469 & 4032.287 & -2.474 & 0.0897 \\
\hline $\mathbf{R}^{2}$ & \multicolumn{4}{|l|}{0.898016} & \multicolumn{4}{|l|}{0.888063} \\
\hline $\begin{array}{l}\text { Adjusted } \\
\mathbf{R}^{2}\end{array}$ & \multicolumn{4}{|l|}{0.745041} & \multicolumn{4}{|l|}{0.776126} \\
\hline F-Statistic & \multicolumn{4}{|l|}{5.870335} & \multicolumn{4}{|l|}{7.933609} \\
\hline $\begin{array}{l}\text { Prob (F- } \\
\text { Statistic) }\end{array}$ & \multicolumn{4}{|l|}{0.149006} & \multicolumn{4}{|l|}{ 0.041399* } \\
\hline
\end{tabular}

$\mathrm{PAT}=\alpha_{0}+\beta_{1} C O S A+\beta_{2}$ TOTINV $+\beta_{3 N O E}+1 t$

$\begin{array}{ll}\text { PAT }=380264+0.119292 \mathrm{COSA}-0.049096 \mathrm{TOTINV}-77.61601 \mathrm{NOE} & \text { Before } \\ \text { PAT }=18176132-0.260971 \mathrm{COSA}+0.626734 \mathrm{TOTINV}-9977.469 \mathrm{NOE} & \text { After }\end{array}$

Table 3 shows the multiple regression result of the effect of lean implementation measured by cost of sale (COSA), total inventory (TOTINV) and number of employees (NOE) on profit after tax (PAT) of Cadbury Nigeria Plc before and after the implementation of the lean system. The result reveals that for the period before the adoption of the lean system, COSA has a positive effect on PAT, while both TOTINV and NOE have negative effect on PAT. The period after the implementation of the lean system shows that TOTINV has a positive effect on PAT, while both COSA and NOE have negative effect on PAT as revealed by the signs of the coefficients which may be as a result of the company not optimally scaling down some of her input to derive the full benefit that comes from the adoption of the lean system.

Also, the size of the coefficients shows that before the implementation of the lean system, 1 change in COSA and TOTINV caused a $¥ 0.119$ increase (in Thousand) and $¥ 0.049$ decrease (in Thousand) in PAT respectively, while one employee added to the workforce of Cadbury also resulted in $\$ 7$ increase (in Thousand) in PAT. However, the size of the coefficients after the implementation of the lean system shows that a 1 change in COSA and TOTINV brought about a $\$ 0.261$ decrease (in Thousand) and $\$ 0.627$ increase (in Thousand) in PAT respectively, while one employee added to the workforce of Cadbury reduced the firms PAT by 9977 decrease (in Thousand).

Furthermore, the Adjusted R-squared shows that about $75 \%$ variations in PAT before the implementation of lean can be attributed to the influence of all our explanatory variables while the remaining $25 \%$ variations in the respective 
dependent variable were caused by other factors not included in this model. Also, the adjusted R-squared for the period after the implementation of the lean system showed that about $78 \%$ variations in PAT was attributed to the influence of the explanatory variables while the remaining $22 \%$ variations in the PAT are caused by other factors not captured in the model. This implies that the lean implementation variables are more effective on the Profit after tax of Cadbury Nigeria Plc.

The probability of the F-statistic of the models stood at $15 \%$ and $4 \%$ for the period before and after the implementation of lean respectively. Implying that Cost of sales, total Inventory and Number of employees have an insignificant effect on Profit after Tax of Cadbury Nig. Plc before the implementation of the lean system while after the implementation of lean, COSA, TOTINV, and NOE have a significant effect on PAT. Therefore, it can be concluded that Lean manufacturing adoption and implementation affected the Profit after Tax of Cadbury Nigeria Plc. On the strength of statistical results obtained from the sampled firms, the work concludes that leanness in the cost of sales, inventory, and labour will stimulate upward growth in profit. However, firm's internal capabilities to adopt and implement leanness philosophy tell the difference between firms that are financial successful and or failure.

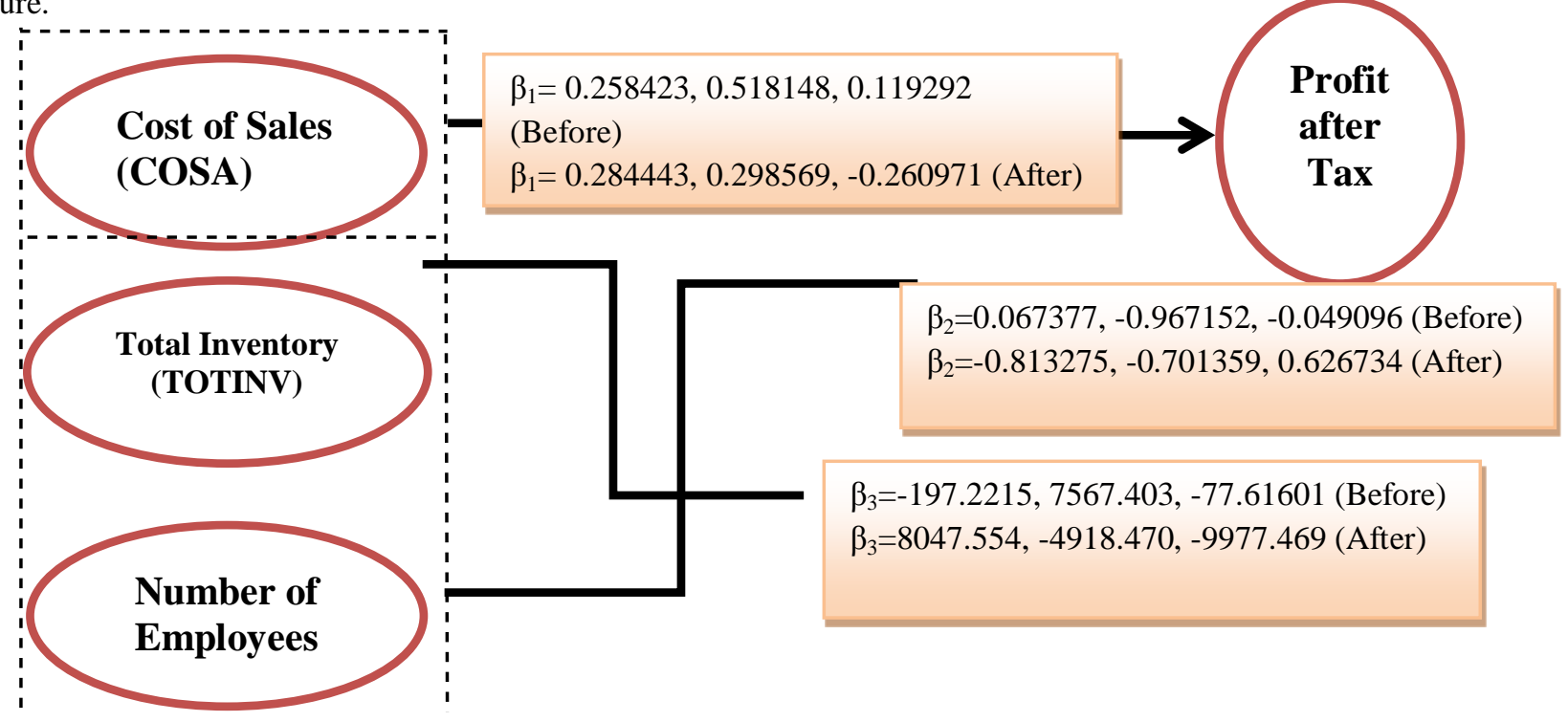

Source: Researcher's Study 2019

Figure 1:-A comparative outlook of the Three DMU's

Figure 1 shows the synergy of the three inputs to show the interdependence between the three input resources and its effect on profit. From the figure above cost of sales of Nestle improved the PAT after the adoption of the lean system but that of Unilever and Cadbury showed no significant effect on the PAT. In the same vein, Cadbury's total inventory improved their profit level after the implementation of the lean system while that of Nestle and Unilever showed no improvement in profit. The employee's utilization of Nestle improved after the implementation of the lean system which also improved the profit level but that of Unilever and Cadbury showed no improvement in employee utilization which also affected the profit level. The figure shows a snap shot of the comparative outlook of the three DMU's which shows the interrelationship between the three inputs and how it affects the profit after tax. The cost of sales, inventory and employees engaged must be optimally utilized for profit to be maximized.

\section{Discussion of Findings:-}

Great controversies still exist in literature on how adoption and implementation of the lean system affects profit. Scholars such as (Chamazkoti et al., 2012; Danatus, et al., 2014; Kumar et al., 2012; Mwelu et al., 2014) discovered that lean manufacturing enhances workforce relations, information sharing, time efficiency, product quality and boost customer satisfaction, reduces costs and invariably exerts a positive influence on profitability. While others (Okpala, 2012; Panizzolo et al., 2012) take a neutral position as lean manufacturing provided no effect on profitability from their respective studies. An opposite perspective was observed from the studies of Camuffo and Volpato (1995) and Khlat, Harb, and Kassem (2014) that introduction of lean system had negative effect on profitability of firms. 
This study concurred with the initial findings of earlier scholars (Chamazkoti et al, 2012; Danatus et al., 2014; Kumaret et al., 2012; Mwelu et al., 2014), that confirmed that lean manufacturing system provides positive significant effects on the profitability of firms. However, Unilever, results showed no significant difference in its profitability between their pre-and post-lean period, this could be attributed to several other internal factors which bear resemblance to Okpala (2013), Vinodh and Joy (2012), and Panizzolo et al (2012): lack of adequate training of employees on handling changes, internal resistance, lack of knowledge, poor employee participation and lack of top management commitment. From the outlook of the findings, Lean manufacturing system adoption requires a fullyfledged people, market, and system reengineering and sensitization to drive profit growth.

Heymans (2016) identified impediments to attaining the benefits from lean system adoption and implementation: challenging leadership and failure to link the processes with normal work, and lack of patience. While these factors are not similar to the construct of this study, leadership in inventory leanness, labour leanness, and cost could enable the firms' aggregate cost to drop, market pricing becomes competitive, and profit to grow. As such, internal cost control yields financial performance. Hence, internal right process or system will produce the right result; which implies that if a firm correctly implements the lean process, the profit of the company will improve.

\section{Conclusion and Recommendation:-}

This paper investigated the effect of lean manufacturing system (inventory, employees, and cost of sales) on profitability of selected food and beverages companies within the Nigerian manufacturing sector. The results revealed that Nestle and Cadbury observed positive changes in their profitability as a result of the lean implementation, but otherwise for Unilever in the pre-post implementation eras. Thus, the study concluded that although lean manufacturing system contributed to profit growth internal improvement especially in waste reduction increases profitability.

The study recommends that companies seeking to adopt the lean manufacturing system must engineer internal process and systems before adoption. The internal refinement paves the path for innovativeness in process targeted at improving sales, efficiency in inventory and labour by constantly driving down cost across operations. Empirical contributions were evident in lean manufacturing system and profitability in concepts and findings from the Nigerian manufacturing food and beverages sub-sector perspective. Nevertheless, further studies will be needed in lean manufacturing profitability but from the point of return on asset or return on capital employed, and internal learning and growth as moderator.

\section{References:-}

1. Akinwale, Y. O., Dada, A. D., Oluwadare, A. J., Jesuleye, O. A., \& Siyanbola, W. O. (2012). Understanding the nexus of R\&D, innovation and economic growth in Nigeria. International Business Research, 5 (11), 187-196.

2. Alhuraish, I.; Robledo, C.; Kobi, A. (2016). Assessment of lean manufacturing and six sigma operation with decision making based on the analytic hierarchy process. IFAC, 49, 59-64.

3. Almusawi, E., Almagtome, A., \& Shaker, A. S. (2019). Impact of lean manufacturing information on the financial performance of the healthcare institutions: A case study. Journal of Engineering and Applied Sciences, 14(2), 589-599.

4. Amos, N. B. (2017). Lean manufacturing and performance optimization in multinational food and beverages companies in Nigeria. (Unpublished Doctoral thesis), Babcock University, Ogun State, Nigeria.

5. Braiden, B.W., \& Morrison, K.R. (1996). Lean manufacturing optimization of automotive motor compartment system. Computers and Industrial Engine, 31(1\& 2), 99-102.

6. Camuffo, A. \& Volpato, G. (1995). The labour relations heritage and lean manufacturing at Fiat. The International Journal of Human Resource Management, 6(4), 795-824.

7. Chamazkoti, H. E., Namadchian, H., \& Davoudi, S. M. (2012). The impact of lean production on firms' profitability. A Journal of Economics and Management, 1(7), 1-9.

8. Egwakhe, A. J., Adefulu, A., Ariguzo, V. A. (2019). Export-preneurial behaviours and profitability of selected non-oil enterprises in South-western Nigeria. International Journal Advanced Research, 7(4), 641-651.

9. Heymans, B. (2015). Lean manufacturing and the food industry. Retrieved from http://www.flowmakers.com/article/ Articlefoodindustryandkaizen.pdf

10. Hoang, P. B. (2015). Relationship of export market orientation, selected export strategy, and export performance: An empirical study. Global Journal of Management and Business Research: E-Marketing, 15(6), $1-9$. 
11. Keitany, P., \& Riwo-Abudho, M. (2014). Effects of lean production on organizational performance: A case study of flour producing company in Kenya. European Journal of Logistics Purchasing and Supply Chain Management, 2(2), 1-14.

12. Khlat, M., Harb, A. H., \& Kassem, A. (2014). Lean manufacturing: Implementation and assessment in the Lebanese pharmaceutical industry. International Journal of Computing and Optimization, 1(2), 47-62.

13. Kumar, R. M., Dhermendra, M., \& Naveen K. M. (2012). An exploratory study on implementation of lean manufacturing practices (With Special Reference to Automobile Sector Industry).

14. Lainos, I. (2011). Red ocean vs blue ocean strategies. (Unpublished masters thesis), University of Piraeus.

15. Modi, D. B., \& Thakkar, H. (2014). Lean thinking: Reduction of waste, lead time, cost through lean manufacturing tools and technique. International Journal of Emerging Technology and Advanced Engineering, 4(3), 339-344.

16. Mwelu, N., Rulangaranga, D. M., Watundu, S., \& Tindiwensi, C. K. (2014). Lean manufacturing and profitability of manufacturing firms in Uganda. European Journal of Business and Management, 6(18), 187190.

17. Nkeiru O. (2019, August 1). MAN CEO's Confidence index: Weaker manufacturing performance recorded in 2nd quarter of 2019. The Corporate News $360^{\circ}$. Retrieved from https://thecorporatenews360.com/uncategorized/article/man-ceos-confidence-index-weaker-manufacturingperformance-recorded-in-2nd-quarter-of-2019/

18. Okon, A. (2019, May 26). MAN blames 2019 elections for declining Q1 GDP growth. The Punch Newspaper. Retrieved from https://punchng.com/man-blames-2019-elections-for-declining-q1-gdp-growth/

19. Okpala, K. E. (2013). Lean six sigma methodologies and organizational profitability: A review of manufacturing SMEs in Nigeria. American Journal of Industrial and Business Management, 3(1), 573-582.

20. Onuba, I. (2018, June 4). Manufacturers suffer N30bn revenue decline in three months. The Punch Newspaper. Retrieved from https://punchng.com/manufacturers-suffer-n30bn-revenue-decline-in-three-months/

21. Onuba, I. (2019, June 2). Manufacturing sector's output drops by N78bn in three months. The Punch Newspaper. Retrieved from https://punchng.com/manufacturing-sectors-output-drops-by-n78bn-in-threemonths/

22. Onwughalu, O.O., Okeke, K.E., \& Henry-Chibor, E. (2017). Lean production and its effect in organizations: A study of selected manufacturing firms in Nigeria. Scholarly Journal of Science Research and Essay, 6(4), 85-98.

23. Owolabi, S. A, \& Obida, S. S. (2012). Liquidity management and corporate profitability: Case study of selected manufacturing companies listed on the Nigerian Stock Exchange. Business Management Dynamics, 2(2), 1025.

24. Panizzolo R., Garengo, P., Sharma, M. K. \& Gore, A. (2012). Lean manufacturing in developing countries: evidence from Indian SMEs, production planning \& control: The management of operations, 23(10/11), 769788.

25. Sivathaasan, N., Tharanika, R., Sinthuja, M., \& Hanitha, V. (2013). Factors determining profitability: A study of selected manufacturing companies listed on Colombo Stock Exchange in Sri Lanka. European Journal of Business and management, 5(27), 99-107.

26. Smeds, R. (1994). Managing change towards lean enterprises. International Journal of Operations and Production Management, 14(3), 66-82.

27. Snee, R. D. (2010). Lean six sigma-getting better all the time. International Journal Lean Six Sigma, 1, 9-29.

28. Ududechinyere, C., Eze, O. M., \& Nweke, A. M. (2018). An analysis of the effect of manufacturing sector on the growth of the Nigerian economy. IOSR Journal of Business and Management (IOSR-JBM), 20(4), 34-46.

29. Wafa, M. A., Yasin, M. M., \& Swinehart, K. (1996). The Impact of supplier proximity of JIT success: An informational perspective. International Journal of Physical Distribution and logistics Management, 26(3), 2334.

30. Vinodh, S., \& Joy, D. (2012). Structural equation modelling of lean manufacturing practices. International Journal of Production Research, 50(6), 1598-1607. 